\title{
FAMILY CELEBRATIONS
} IN LITHUANIA AND BULGARIA: ETHNIC, CONFESSIONAL AND CULTURAL TRAITS

\section{Rasa Paukštytè-Šakniene}

Department of Ethnology and Anthropology, Lithuanian Institute of History, Vilnius, Lithuania

e-mail:rasa.sakniene@gmail.com

\begin{abstract}
The article is aimed at answering the question whether confessional and ethnic background has an impact on the holiday traditions that bring family members together. The investigation focuses on Christmas as it was qualified as the most important family celebration by both - citizens of Vilnius and those of Sofia. Analysis of Christmas as celebrated in the $19^{\text {th }}$ early $20^{\text {th }}$ century revealed that Lithuanians and Bulgarians give particular prominence to Christmas Eve, and neither differences in the geographic environment and history nor Baltic and Slavic ethnic and Catholic and Orthodox religious background resulted in any significant distinctive features. In the second half of the $20^{\text {th }}$ century the festival in question was considered illegal in the regions under investigation. In the late $20^{\text {th }}$ - early $21^{\text {st }}$ century Christmas Eve became the most important celebration that brings the family together in the cities subjected to investigation. Moreover, the research revealed that Christmas as observed by Orthodox Bulgarians in Sofia is more akin to the festival observed by Catholic Lithuanians and Poles in Vilnius than to that celebrated by Orthodox Russians.
\end{abstract}

Keywords: Balts, Christmas, Christmas Eve, ethnic, religious, and cultural identity, family, holiday, Slavs 
Analysis of calendar festivals observed by modern families of Vilnius citizens of Lithuanian, Polish, and Russian nationality revealed that despite the aftereffects of the Soviet atheist policy and latter-day secularization processes, religious aspects have retained importance. Old Ritualists and Orthodox Russians observe Christian festivals according to the Julian calendar, whereas Catholic Lithuanians and Poles use the Gregorian calendar. ${ }^{1}$ The difference between the festivals observed in accordance with the two calendars is 13 days. Therefore, people of the abovementioned confessions (usually Russians) in Lithuania celebrate Christmas after the New Year - on the $7^{\text {th }}$ of January (Vyšniauskaite 1993: 6). However, different confessions are distinct not only by the date of the festival. Investigation of festivals celebrated by the citizens of Vilnius revealed that Catholics, unlike Orthodox people and Old Ritualists, give particular prominence to Christmas Eve. Certain ethnic group related peculiarities, especially pertaining to festive food, can be distinguished. The investigation exhibited that in the festivals observed by the citizens of Vilnius religious factors are accountable for more similarities than the ethnic background. Analysis of Christmas and Christmas Eve does not suggest of the cultural affinity or distinction of the Slavic nations (Poles and Russians) as compared to the Balts (Lithuanians) (Paukštytė-Šaknienè 2016b: 29-74). The said findings prompted to conduct an investigation in a city of a different country, namely Sofia. Although Vilnius and Sofia are capitals of two independent states of the European Union, they are characterized by quite distinct history. After WWII Bulgaria became a Socialist country, whereas Lithuania was incorporated into the USSR as one of its republics. The two cities also differ in their geographic location, ethnic and confessional structure ${ }^{2}$ and a number of other factors which in the comparative analysis might translate into tangible differences. As Orthodox and Slavs Bulgarians could be compared to the Russian population of Vilnius which for the most part is also Orthodox. And the Slavic background ought to be important. For example, Bulgarian researcher Rachko Popov spotted the similarities of winter and spring festivals and their rituals characteristic of Slavic ethnic groups and coupled them with the common background (Popov 1989: 73-74). On the other hand, Slavic peoples may profess different beliefs and the Orthodox faith in different countries may also manifest certain distinctions. Calendars used by Orthodox people in Lithuania and Bulgaria differ. On 12 March 1916 the Bulgarian parliament adopted the law providing for the introduction of the Gregorian calendar. Bulgarian Orthodox Church, however, 
continued to use the Julian calendar until 1968 when Bulgarian, Romanian, and Greek Orthodox Church adopted the Gregorian calendar, and today only the Easter cycle festivals are continued to be observed according to the Julian calendar (Introduction...). Thereby, Easter time in Bulgaria corresponds with that of the Orthodox Russians, whereas Christmas is celebrated together with Roman Catholics. Another Slavic nation - Poland - adopted the Gregorian calendar together with the Grand Duchy of Lithuania at the end of the $16^{\text {th }}$ century.

Despite the Christian origin of the festival in question, there are certain differences in the folk traditions observed by Balts (Lithuanians and Latvians) and Slavs as part of the celebration. By comparing these traditions from the perspective of time and location we will strive to answer the question whether religious and ethnic background plays an important role in the traditional celebration of festivals that bring the family together.

The main source of the article comprises field investigation material collected in Vilnius in 2012-2016 within the framework of the projects "Social Interaction and Cultural Manifestations in the City: Leisure Time, Festivals, and Rituals in 2012-2016" and "Contemporary Festivals in the Families of Vilnius Citizens in 2014-2016" and in Sofia in 2015 conducting the project "Contemporary Festivity in Bulgaria and Lithuania - from Traditional Culture to Post-Modern Transformations in 2014-2016". Based on the said material and additional ethnological research conducted by other authors, the author of this article attempts to compare Christmas as the family celebration in two different cities in the period from 1950 to 2015.

\section{Traditional Slavic and Baltic Christmas and Christmas Eve}

Christmas - Jesus Christ's birthday - stands out in the structure of the ritual year among the majority of Christian nations. In East Lithuania in the mid$20^{\text {th }}$ century Christmas was celebrated for four or even twelve days until the Epiphany (6 $6^{\text {th }}$ of January) (Šaknys 2001:39). In the modern-day Lithuania this festival also stands out for its duration - in 1990 Christmas and Boxing Day were declared public holidays, whereas in 2012 another day-off - Christmas Eve - was added to the festive season. In Bulgaria the tree days are also considered official days-off. As in the past Bulgarians, similarly to most European nations, gave prominence to the 12-day period starting with Christmas (Slaveikov 2012: 12). 
Public discussions that took place in Lithuania in 2012 with regard to the declaration of Christmas Eve a public holiday emphasized the need to prepare for the celebration of Christmas. However, ethnographic descriptions of Christmas for the most part focus on Christmas Eve rather than Christmas. For example, in ethnologist Juozas Kudirka's book "Christmas Eve and Christmas in Lithuania", which is considered the most exhaustive analysis of Christmas and Christmas Eve as celebrated in the late $19^{\text {th }}$-early $20^{\text {th }}$ century, Christmas Eve is given way more consideration than Christmas. When describing the day of Christmas Eve the ethnologist highlights spiritual purification (fasting, reconciliation with one's neighbours, payment of debts), work that should be done exceptionally by men and women, and pre-Christmas visit to the bathhouse. Descriptions of the night of Christmas Eve feature decorations of the room (the nativity crib, Christmas tree, sheaf of corn) and preparation for the festival. Christmas Eve dishes, course of the dinner, predictions of the future, and various beliefs related to Christmas Eve are described in detail. A much smaller part of the book is dedicated to Christmas - it features the description of going to the church and getting back on Christmas morning, Christmas breakfast, Father Christmas, sanctification of oats on Boxing Day, seeing off of the hired workers, and Christmas games (Kudirka 1993: 34-243). Thus, the focus is on Christmas Eve dinner. When writing about Christmas as observed by the Poles of Vilnius region in the mid- $20^{\text {th }}$ century, researcher Maria Znamierowska-Prüfferowa also focused her attention on the description of the Christmas Eve dinner and traditional dishes, whereas the description of Christmas was confined to a few sentences. Traditional Polish Christmas Eve dishes described by the abovementioned author are akin to those served by Lithuanians (Znamierowska-Prüfferowa 2009: 141-145). Preparations for the festive season and family reunions on Christmas Eve were also emphasized by respondents that had been questioned in the course of the research, though the focus here for the most part was on the social aspect of Christmas Eve, i.e. the possibility to spend time with the family.

Similarly, in Bulgaria emphasis is also laid on Christmas Eve dinner. For example, in Racho Sleveikov's book Christmas Eve, though called Little Christmas (Malka Koleda), is described in greater detail than Christmas itself (Slaveikov 2012: 9-20, 158-160). According to researcher T. A. Koleva, Christmas Eve dinner in the late $19^{\text {th }}$-early $20^{\text {th }}$ century Bulgaria was a solemn occasion. People would sit around a small round table or on the ground, hay would be laid under 
the table or table cloth. Traditionally 9-12 lenten dishes prepared from what was grown on the farm were served: beans, stuffed peppers, cabbage rolls, layered pumkin pie, "kutia", vodka, wine, corn ears, salt, nuts, garlic, and stewed fruit. Traditionally the oldest person in the family would take a handful of hay from the table and fumigate the hives. This was a rite of purification intended to scare away evil spirits. Upon return the head of the family would bow three times in front of the dinner table, take the bread, raise it above his head and break to pieces. Then, he would offer the first piece of bread to all members of the family, so that they could take a small crumb. One piece of bread would be left until the morning and then given to farm animals, another one would be placed under the icon, third one - near the fireplace "for the deceased parents/ relatives". The remaining bread would be placed high on a shelf (usually situated along a wall in Bulgarian houses), so that the corn grows tall. Traditionally members of the family would not leave the table during the dinner, whereas the head of the family would walk around the table with his head down so that corn ears grow heavy and lean down. Ritual dishes would be taken off the table in the morning and then the children would slide down the hay stack from one side so that the corn leans to one side. Later, the hay would be used to tie around a fruitless plant/tree or would be kept until Saint George's Day when it would be burnt on a grapevine to "protect from thunder". Numerous rituals were used to predict the future: a silver coin found in food would mean good fortune, full nut - health, empty nut - illness. Girls would not eat their crumbs of the ritual bread rather putting them under their pillows in hope of seeing their future husband in a dream (Koleva 1977: 272).

Christmas Eve dinner in Lithuania in the period in question differed in the selection of dishes predetermined by a more severe climate. Catholic faith is accountable for the prominence laid in the Christmas wafer which can be associated with bread in Bulgaria. In Lithuania there was no tradition to put coins or other things into bread or pastries, besides, Christmas Eve dishes in Lithuania were made without animal fat, only vegetable oil was used. Dishes were prepared using legume crops (peas and beans) and cereals (oats, wheat, barley), poppy, hemp, and flax seeds, vegetables (potatoes, beetroots, cabbages, carrots), and other delicacies gathered in the forest (mushrooms, nuts, cranberries) and garden (apples, cherries, honey). Herring and other types of fish was a mandatory dish on the Christmas Eve table. Similarly to Bulgaria, in Lithuania hay was also laid under the table cloth before Christmas Eve dinner, food was 
left on the table overnight (for the souls of the deceased) and the hay was used to tie around apple, pear, and plum trees (Kudirka 1993: 64, 118-122, 169-172).

However, comparison of the festivals in Lithuania and Bulgaria may reveal other differences. Although the words for Christmas in Lithuanian and Bulgarian languages are somewhat similar (Lith. Kaledos, Bulg. Коляда), words used to denote Christmas Eve in the two languages are completely different (Lith. Küčios, Bulg. Бъднивечер). In the course of history linguists have come up with a number of explanations concerning the derivation of the word Küčios. Today, the words kū̌cia, kūčios are used not only to denote Christmas Eve, but also the Christmas Eve dinner and in some regions also certain dishes served during the dinner (Kudirka 1993: 15-17). Bulgarian name of the festival may be associated with the ritual tree бъдняк. For example, according to Bronislava Kerbelyte, alms collecting is a specific feature in the celebration of Christmas Eve among East Slavs, whereas the ritual of badnjak is typical of South Slavs who would cut a tree or a tree stump, carry it around houses, later placing it on the fire (Kerbelyte 2012:31-48). N. I. Tolstoi distinguished this ritual as the central ritual of the Christmas cycle among South Slavs (Tolstoi 1995: 127-131). On the other hand, in the past similar rituals were considered significant among Balts as well. For example, in Latvia - the other Baltic country - Christmas Eve was also associated with a tree and called Bluka vakars (Olupe 1992: 9). Sources suggest that back in the $18^{\text {th }}$ century a log would be dragged around and later burnt in the territory of the present-day Latvia. In Lithuania this custom is only found in the $19^{\text {th }}$ century sources (Kudirka 1993: 234-242). ${ }^{3}$ This makes it obvious that analysis of ancient Lithuanian and Bulgarian festivals may reveal certain similarities that were retained disregarding different geographic environment and history, Baltic and Slavic ethnic and Catholic and Orthodox religious backgrounds.

\section{Christmas and Christmas Eve in Urban Families}

In the Socialist period Christmas could not gain any significant differences. According to Dilyana Ivanova, the leading ideological structures in Socialist Bulgaria managed to form a new concept of national heritage aimed at entrenching the said concept in each and every sphere of life. An important role was played by the newly formed Socialist festive culture which encompassed new "Socialist" events and rituals as well as traditional festivals free of religious and 
"bourgeois" content (Ivanova 2015: 332). Following the Soviet occupation of Lithuania, the system of calendar holidays underwent substantial changes. The only public holidays were revolution-related festivals (with the exception of New Year's Day). Moreover, new folk festivals that suited the cultural peculiarities of the newly-formed Lithuanian SSR were introduced. Throughout the Soviet period the concept of "new traditions" aimed at legitimizing the newly-developed festive rituals was being actively framed (Paukštytė-Šaknienè 2016a: 25-26). However, in the last decade of the $20^{\text {th }}$ century both the countries witnessed the traditional customs' restoration process whose results can be recorded in the course of our field investigation.

A respondent (b. 1933), who moved to Sofia in 1959, claimed that though under the Socialist rule the celebration of Christmas was forbidden, people continued to celebrate within their families, at times secretly. During that period none of the church festivals was officially recognized. A woman born in 1941 and living in Sofia since 1961 said that while her parents were alive the family would gather at their house for Christmas Eve. Today, the centre of family gatherings is her home where her closest ones - children and grandchildren - come. They bake bread - numa - for Christmas and by all means make pork dishes or stuffed turkey - this is the tradition she brought along from her village (the woman was born in Southeast Bulgaria, near the Turkish border). On Christmas Eve, however, the family restrain from eating meat, usually the served dishes contain beans and fresh vegetables. Sweet pie - нyzaчe - is baked.

Part of the respondents claimed that they had not celebrated Christmas before "democracy" and then it became the most important family celebration. According to the respondent born in 1952 in Sofia, seven, nine or thirteen dishes are served during the Christmas Eve dinner. At least seven dishes should be on the table. The indispensable Christmas Eve dishes include cabbage rolls and bread - баница or numa - with secrets - каемет - inside: a piece of the hardest wood, coins, or pieces of paper containing wishes. Bread is usually broken and distributed by the oldest member of the family. On the Christmas Eve dinner table there should always be nuts to keep the diners strong and healthy and garlic to protect from the evil eye and also help stay healthy. After midnight the fast is over and eating meat is allowed. On Christmas day solemn family lunch and dinner are arranged. On Boxing Day people go out to visit their friends and relatives, exchange presents. Usually things that would cheer the receiver or would be useful to him/her are given as presents. Something 
is brought to the house of the hosts, for instance, a blender, a pot, a grater, or a coffee-pot - so that the house is cosy and the family has everything it might need. According to the woman, earlier natural fir-trees were decorated, but today, due to environmental considerations, they use an artificial Christmas tree. Presents are exchanged on Christmas Day - in the morning of the $25^{\text {th }}$ of December - in the respondent's family first of all children get their presents and then adults exchange theirs. The respondent has noticed that some people use stockings to put their presents in, but she does not like the new trend. The woman tends to stick to her family's traditions.

All respondents emphasized that Christmas Eve is a family celebration, however, the majority of them also related to Christmas as a family festival. A woman born in 1948 who relocated to Sofia in 1970 claimed that she always celebrates Christmas Eve and Christmas exclusively with her family. A man born in 1966 and living in Sofia since 1979 also said that he always has Christmas Eve dinner together with the immediate family. The next day, i.e. at Christmas, his parents come to visit, whereas on the third day (Boxing Day) he celebrates together with his friends. At times different traditions are observed. In the family of a woman born in 1945 there is a tradition that on Boxing Day children (now grandchildren) go to visit their neighbours and give them red and blue braids as protection from the evil eye. This is related to health. According to a woman born in 1953, on Christmas morning their family always go to church (although this is not typical of the majority of the respondents).

Similar celebrations are characteristic of interfaith families. According to a woman born in 1978, Christmas Eve is celebrated together with the parents of one of the spouses, and Christmas (first day) - with the parents of the other spouse. The festival lasts for two days. Her husband's father is Catholic and his mother is Orthodox. On Christmas Eve the father-in-law says a Catholic prayer, but all other customs are Orthodox. An odd number of dishes is served. They eat bread (питка с късмети) with baked in symbols: coin - for wealth, bean - for fertility, tree bud - for health, and button - for work. It is usually the mother or mother-in-law who do the cooking. The oldest person in the family breaks the bread and distributes its pieces to all members of the family. A piece is left for Mary, mother of Jesus - Богородиนи. Traditional Christmas dishes include сарми - cabbage rolls with meat - and stuffed peppers. Besides, чюбрии - a mixture of spices to dip the bread in - is prepared. The family of the respondent consider it important to have ymaв - dried fruit stew - on the 
table. Presents are placed under the Christmas tree on Christmas Eve or after midnight and unwrapped on Christmas morning.

At times more remote relatives get together on Christmas Day and the younger generation of Sofia citizens claim that on this day it is allowable to invite friends. Younger respondents' stories suggest that alongside the old traditions new practices are being introduced. For example, according to a woman born in 1990, they have a family tradition to look through family photos and videos. A respondent born in 1988 claimed that at Christmas she goes to visit her parents as her mother makes traditional salad and her father fries a turkey, but the woman named the possibility to spend this time of the year with her parents rather than the traditional dishes as the main reason for going to her parents. Here Marija Prodanova's words that Christmas Eve "is about home, family, and affectionate communication" (Prodanova 2013: 201) can be cited.

Christmas Eve is very important to the Catholic Poles living in the largest cities of Bulgaria. In terms of celebration, Bulgarian Poles fall into two groups: those who celebrate according to Polish customs only, and those who celebrate twice, according to Polish and according to Bulgarian tradition or once in a mixed fashion (Mihaylova 2014: 279). One of such Polish traditions is the distribution of opłatek (Lith. kaledaitis - Christmas wafer, i.e. a type of bread made of wheat flour and baked in thin dough layers with depictions of Gospel scenes upon it) (ibid.: 279-280). Besides, different Polish dishes are served, including the sweet cake with poppy seeds or with honey, beetroot soup, and carp which are also known in Lithuania (ibid.: 280).

Citizens of Vilnius also appreciate the possibility to spend time with their families. Christmas Eve and Christmas Day are usually dedicated to the family, whereas Boxing Day (at times also Christmas Day) are for going out and visiting friends. For example, a respondent born in 1990 claimed: "Of all the festivals I like Christmas best because it is a family occasion with a special atmosphere - people eradiating kindness, delicious food, the smell of the Christmas tree, the spirit of Father Christmas. It takes about a week to get ready for Christmas: we decorate the house and buy the Christmas tree. Then, in the morning usually my father and I decorate the Christmas tree, while my mother is working in the kitchen, later, we go on with wrapping presents, working all day, decorating the dinner table and waiting for our relatives to come. During the dinner we break the Christmas wafers, eat, talk, and finally check what's under the Christmas tree. However, the celebration is not over yet. We go to 
visit my grandma and repeat the whole ritual there." The woman emphasized that this festival is rather special for the whole family. Due to the possibility of the family reunion, a respondent born in 1989 also considers Christmas time an exceptional occasion. The woman claims: "The festival I like is Christmas Eve because I spend it with my parents, brother, and grandad. It is the only occasion that brings all our family together" (Paukštytè-Šaknienè 2013: 313).

For Catholic Lithuanians and Poles Christmas Eve dinner is a particularly important element of the festival as it starts with the sharing of kaledaitis/ opłatek (Christmas wafer) among family members. Usually an even number of dishes - twelve - is served (in the mid-20 ${ }^{\text {th }}$ century Vilnius this tradition was typical not only of Catholics but also of Orthodox families (ZnamierowskaPrüfferowa 2009: 214) which differ from their counterparts in Bulgaria. The recent tendency among Russians is giving less prominence to Christmas Eve dinner than Lithuanians and Poles, however a Russian respondent born in 1991 indicated that it is obligatory to go to the bathhouse before Christmas Eve dinner and during the dinner no less than twelve dishes should be served so that the upcoming year is prosperous for the family (Paukštytė-Šakniené 2016b: 65). On the other hand, Russian respondents, unlike their Lithuanian and Polish colleagues, could hardly identify the most important Christmas Eve dishes. Investigation of typical Christmas Eve dinner food revealed that dishes based on flour and cereals prevail. Fish (including herring) and its dishes are ranked second. Analysis of the most important dishes suggests that Lithuanians cannot imagine Christmas Eve dinner without küčiukai (small, slightly sweet pastries made from leavened dough and poppy seeds), whereas Poles consider fish (particularly carp which is very popular throughout Poland) and Russians - herring - the most important festive food. There is more diversity in traditional Christmas Day food. Lithuanians and Poles mostly prepare meat dishes, dominated by various types of fried chicken. On the tables of Russian families, however, dishes containing no meat prevail. This phenomenon can be coupled with the fact that part of the Russians celebrate Christmas on the 25th of December according to the Gregorian calendar when Russian families are still fasting (Paukštytè-Šaknienè 2016b: 48, 82). There are certain differences in the time of Christmas tree decoration. In Vilnius it is quite obvious that Orthodox people purchase their Christmas trees not prior to Christmas as Catholics do, but after the Catholic Christmas, usually before the New Year's Eve. Ž. Šaknys' investigation revealed that school students receive presents at different time - Poles usually on Christmas Eve, Lithuanians - on Christmas 
morning, and Russians mostly on New Year's Day (Šaknys 2016: 95). Festive church attendance is not always subject to nationality and religion. Polish people usually go to church on Christmas Eve, Lithuanians - on Christmas Eve and on Christmas Day, and Russians also on Christmas Eve, but the latter go to church least frequently of the representatives of the three ethnic groups (Paukštytè-Šaknienè 2016b: 64).

Thus, it can justly be concluded that in the modern families of Vilnius citizens representing the three ethnic groups Christmas Eve and Christmas are considered the most important and valuable family celebration. A considerable part of Russians, however, lay less prominence on Christmas Eve, considering Christmas the most important festival. Respondents in Bulgaria, however, similarly to Lithuanians and Poles, emphasize the significance of Christmas Eve.

\section{Conclusions}

The research revealed that despite secularization, religious factors have retained their importance in the celebration of Christmas. On the other hand, differences have been observed within communities professing the same faith. The fact whether the festival is celebrated in accordance with the Julian or Gregorian calendar is more important to the content of the festival than different religious backgrounds. Most Orthodox and Old Ritualist (Old Believers) Russians of Vilnius celebrate Christmas according to the Julian calendar, i.e. 13 days later than Catholics. Usually their Christmas falls on a workday, therefore the celebration differs from that on a day-off. Another important aspect is the fact that Russians are apt to focus on the celebration of the first of January, thus showing less consideration for Christmas Eve and Christmas that are celebrated later. However, for Bulgarians who celebrate in accordance with the Gregorian calendar, Christmas and especially Christmas Eve have retained greater importance.

Cultural memory also plays an important role in the form of the festival, though certain archaic elements of the celebration (for instance, dragging and burning of a tree) cannot be exercised in modern cities. On the other hand, certain traditional features of the festival that have been passed down from generation to generation as well as days-off dedicated to celebration facilitate family reunions in the urban environment and allow representatives of different generations qualify Christmas as the most important family and personal celebration of the year. 


\section{Notes}

1 In the bigger part of the territory of the present-day Lithuania the Gregorian calendar was introduced in 1586. In 1800 the country reverted to the Julian calendar and the Gregorian calendar was reintroduced in 1915. Orthodox people and Old Believers in Lithuania continue to use the Julian calendar.

2 The population of Vilnius is made up of $65.49 \%$ Catholics; $8.93 \%$ - Orthodox people; $1.04 \%$ - Old Ritualists. From the ethnic point of view $63.2 \%$ are Lithuanians; $16.5 \%$ Polish; $12 \%$ - Russians. In Sofia $69.1 \%$ of the total population are Orthodox people; $0.8 \%$ - Protestants; $0.5 \%$ - Muslims. From the ethnic point of view $87.9 \%$ of the city's population are Bulgarians; $1.5 \%$ - Gypsies; $0.5 \%$ - Turks. Thus, the population of Sofia is more homogeneous from both - ethnic and religious point of view.

3 The custom of log dragging was much more typical of Shrove where it was still observed in the second half of the $20^{\text {th }}$ century (Vaicekauskas 2005: 77-78).

\section{References}

Ivanova, Dilyana 2005. Socialist Legacy and Transformations of Cultural Heritage in the Contemporary Forms of Community Gatherings of the Bulgarian Diaspora in the USA, Ana Luleva, In: I. Petrova \& S. Barlieva (eds.) Contested Heritage and Identities in Post-socialist Bulgaria. Sofia: Gutenberg Publishing House, pp. 331-358.

Kerbelytė, Bronislava 2012. Slavu folkloras [Slavic Folklore]. Kaunas: Vytauto Didžiojo Universitetas.

Koleva, T. A. 1977. Bolgary [Bulgarians]. In: S. A. Tokarev (ed.) Kalendarnyye obychai $i$ obryady $v$ stranakh zarubezhnoy Yevropy XIX - nachalo XX v. Zimniye prazdniki. [Calendar Customs and Rituals in Foreign Countries of Europe in $19^{\text {th }}-$ Beggining of the $20^{\text {th }}$ C. Winter Festivals]. Moskva: Nauka, pp. 266-283.

Kudirka, Juozas. 1993. Lietuviškos Kūčios ir Kaledos [Lithuanian Christmas Eve and Christmas]. Vilnius: Vaga.

Mihaylova, Katya 2014. The Ritual Year of the Contemporary Polish Migrant Community in Bulgaria. In: Dobrinka Parusheva \& Lina Gergova (eds.) Migrations. The Ritual Year 8. The Yearbook of the SIEF Working Group on the Ritual Year. Sofia: Paradigma, pp. 274-285.

Olupe, Edīte 1992. Latviešu gadskārtu ieražas [Latvian Calendar Customs]. Rīga: Avots. 
Paukštytė-Šaknienè, Rasa 2013. Tradicija šiuolaikinių kalendorinių ir gyvenimo ciklo švenčių kontekste [Tradition in the Context of Contemporary Calendar and Life Cycle Festivals]. Res humanitariae, Vol. 14, pp. 303-322.

Paukštytė-Šaknienė, Rasa 2016a. Šeima ir kalendorinès šventès sovietinejje Lietuvoje [Family and Calendar Holidays in Soviet Lithuania]. Lietuvos etnologija. Socialines antropologijos ir etnologijos studijos, Vol. 16 (25), pp. 9-34.

Paukštytė-Šaknienè, Rasa 2016b. Kūčios ir Kalèdos [Christmas Eve and Christmas]. In: R. Paukštytè-Šaknienè (ed.) Šventès šiuolaikinèje vilniečiu šeimoje [Holidays in the Contemporary Family of Vilnius Inhabitants]. Vilnius: Lietuvos istorijos institutas, pp. 30-73.

Popov, Rachko 1989. Kŭm kharakteristikata na bŭlgarskite narodni vyarvaniya, svŭrzani s periodite na prekhod kŭm zimata i proletta [On the Characterization of Bulgarian Folk Beliefs Connected with the Periods of Transition to Winter and Spring]. Etnografski problemi na narodnata dukhovna kultura [Ethnographical Problems of Folk Traditional Culture]. Sofiya: Izdatelstvo na Bŭlgarskata akademiya na naukite, pp. 52-74.

Prodanova, Mariya 2013. Bolgarskie prazdniki i traditsii [Bulgarian Festivals and Traditions]. Sofiya: Bard.

Šaknys, Žilvytis 2001. Kalendoriniai ir darbo papročiai Lietuvoje XIX a. pabaigoje $\mathrm{XX}$ a. pirmoje puseje: Jaunimo vakarèliai [Lithuanian Calendar and Work Customs in the Late $19^{\text {th }}-1^{\text {st }}$ Half of the $20^{\text {th }}$ Centuries: Youth Parties]. Vilnius: Diemedžio leidykla.

Šaknys, Žilvytis 2016. Naujieji metai [New Year]. In: R. Paukštytė-Šaknienè (ed.) Šventès šiuolaikineje vilniečių šeimoje [Holidays in the Contemporary Family of Vilnius Inhabitants]. Vilnius: Lietuvos istorijos institutas, pp. 75-104.

Slaveĭkov, Racho 2012. Bŭlgarski narodni obichai i vyarovaniya [Bulgarian Folk Customs and Beliefs]. Sofiya: Knigoizdatelstvo Asenevtsi. First edition 1924.

Tolstoi, Nikita I. (ed.) 1995. Slavyanskiye drevnosti. Etnolingvisticheskiy slovar' [Slavic Antiquities. Ethnolinguistic Dictionary]. Vol. 1. Moskva: Mezhdunarodnyye otnosheniya.

Vaicekauskas, Arūnas 2005. Lietuvių žiemos šventès: Bendruomeninès kalendorinio ciklo apeigos XIX a. pab. - XX a. pr. [Lithuanian Winter Festivals: The Rites of the Community Calendar Cycle in the Late $19^{\text {th }}-$ Early $20^{\text {th }}$ Centuries]. Kaunas: VDU leidykla.

Vyšniauskaitè, Angelè 1993. Mūsų metai ir šventès [Our Years and Festivals]. Kaunas: Šviesa.

Znamierowska-Prüfferowa, Maria 2009. Vilnius, Miestas arčiausia širdies [Vilnius: The City Closest to My Heart]. Vilnius: Alma littera. 
Rasa Paukštytè-Šaknienè

\section{Internet Source}

Introducion of the Gregorian calendar in Bulgaria. Sofia History Museum. Available at http://www.sofiahistorymuseum.bg/bg/\%D1\%81\%D1\%8A\%D0\%B1\%D0\%B8 $\% \mathrm{D} 1 \% 82 \% \mathrm{D} 0 \% \mathrm{~B} 8 \% \mathrm{D} 1 \% 8 \mathrm{~F} /$ item/264-introduction-of-the-gregorian-calendarin-bulgaria, last accessed on 10.01.2018. 